TOM MONTGOMERY-FATE

\title{
Saunter: A Conversation with Henry David Thoreau
}

The saunterer is no more vagrant than the meandering river which is all the while sedulously seeking the shortest route to the sea.

- Henry David Thoreau, "Walking"

Every day I walk the network of trails that wind through the woods of our Michigan farm. This morning I will walk the boundary trail, which follows our land's periphery. Before leaving, I dig out and drop on the table a wad of twenty jangling gold and silver keys-to two cars, the farmhouse, my office, the shed, the garage, the bike locks, the copy room, and who knows what else. Then I pull out a billfold bulging with plastic: Visa and Master and АTM and phone and gift and health insurance cards and licenses and photo IDs. The cash slot is stuffed with receipts and coupons and blank checks, four one-dollar bills, and an individually wrapped Earl Grey tea bag.

Why is this small act, this emptying, so satisfying? And why do I sometimes carry my keys and billfold when I go walking in the woods? Do I imagine I will find a hidden lockbox in the buggy tangle, or a new cash station in the beaver dam near the oxbow?

I walk out of the farmhouse, cross the creek, and soon reach the meadow where I'm lured by the warm sun to sit in the grass. I notice a dimple in the ground behind me, about the size and depth of an Italian plum split in half. With my eyes four inches away I can see a sparkling prism of sticky dew beads: a sheet web (which if actually a sheet would only bed down a small grasshopper). A spider with a head and body like two saffron grains of sand waits on the rainbow of light it has built, listening for prey with all eight legs. Two black ants walking in different directions over the lovely trap on the stable bridge of a green blade of grass have just enough room to pass without pushing the other off. Since the ants don't stop to investigate with their antennae (parts of which serve as both their noses and fingertips), they seem oblivious to the debacle that looms below them. Ah, the tiny life of the tiny ant-no anxiety, or ignorance, or heroism-just food and reproduction and the chemicals that drive them toward it. How much simpler can a life get? 
And how much more meaningless? There are no saunters, just the march toward survival. My guess is the ants would take their keys and billfolds if they could.

I follow the circuitous route of one of the ants for several minutes on all fours. Just when I tire of tracking him I hear it: a slight yet constant clicking noise-the sounds of thousands of ant legs tapping the brittle dry leaves as they walk-like a light, tender rain.

Suddenly ants are everywhere, all moving toward the sandy hill I now notice a few feet away. There are seventy or eighty entry holes leading inside a mound about the size of my head. Little crews of four or five workers are bringing all kinds of things home for their queen-a piece of a June bug's wing, fragments of grass and leaf and lichen. But the biggest prize is a large iridescent green housefly, which is perfectly preserved. None of its legs or wings have yet been bitten off. The eight ants that are carrying the fly are mobbed when they reach the top of the hill, buried by a frenetic swarm of kicking legs. The fly disappears under the writhing mound of ants, and then reemerges on the backs of a half dozen different ants who quickly move it to one of the entry holes and try to push it through. They pull the thorax in, but the head gets stuck. The mob returns, and another cadre pulls out the green carcass and tries to jam it down a different hole. The fifth attempt is successful: the hole is big enough and the fly disappears into the inner world of the hill. I'm relieved. The scene reminds me of a news clip I saw last year while teaching in England: a hooligan riot at a soccer game in Manchester-a chaotic mob of drunks piling in the bleachers, each lost in the sprawl, in some primal instinct to come out on top.

Ants are also intensely aggressive. Ant wars over territory or food result in both sides literally ripping each other into pieces, the killing field a repository of twitching legs. A popular story in Walden, "The Battle of the Ants," describes such a scene. After watching for a while, Thoreau removes a woodchip from the ant battleground, on which an isolated struggle continues. He takes the chip with the warring red and black ants into his cabin and puts it under a glass tumbler. Using it as a crude microscope he describes how the red ant's "breast was all torn away, exposing what vitals he had there to the jaws of the black warrior." He then sympathizes with the "loser": "...the dark carbuncles of the sufferer's eyes shone with ferocity such as war only could excite." 
Thoreau's emotional personification of the soldier ant is laid against a broader analogy_his critique of the Mexican War and the American Revolutionary War and the futility of war in general. The allegory is overt. While watching the ant battle Thoreau comments, "I was myself excited somewhat even as if they had been men. The more you think of it, the less the difference."

But since Thoreau's time, entomologists have discovered much more about those differences. Unlike those English hooligans in Manchester, ants struggle less to come out on top, than to just keep coming out. Relentless and resilient, the ant's fecundity and dominance is due to its altruism, to each ant's selfless performance of a given duty. This cooperative behavior evolved over a hundred million years ago as a means of strengthening defenses against enemies and finding more food. It has been quite successful. Today, though a worker ant is about one millionth the size of a human being, the total weight of all the ants on earth equals the weight of all the people on earth.

"The great strength of ants," writes E.O. Wilson, "is their ability to create tight bonds and complex social arrangements with tiny brains." Their "thought" is not individualized but collective. The interdependence of their world inside the hill is remarkable-particularly in reproduction. The adult ants nurture the eggs and pupae and larvae by licking them, which keeps them from getting moldy. When I first learned this in a college biology class I wanted to personify, to believe it was a sign of affection, that the ants loved. But of course it's not and they don't. The eggs and larvae are covered with a sweet liquid that attracts the adults. They feed the larvae for the same reason. When an adult puts food in its mouth a sweet liquid is secreted as a reward.

In a biology lab we filled a Petri dish with water and then made a little island of sand in the middle. We put red ant pupae on the island and then set the Petri dish a few inches from a mound of sand that contained a colony of red ants. The point was to see if the ants' "nurturing instinct" would cause them to build a bridge of sand to the abandoned pupae. Sure enough, they immediately started carrying and dumping sand and dirt particles into the water until a bridge was formed and they could reach the stranded pupae.

Then the teacher had us do the same experiment without the pupae. And of course the colony of ants did the same thing; they 
built a bridge to the island even though there were no pupae to rescue. Ants always throw sand or dirt in the water as an instinctive survival response to their hill or colony flooding. But the point of the two-part experiment was to remind us that science is subjective and research is literally that-an unending process of searching. The experimenter "arrives" not at some final answer, but at a deeper set of questions. There is always a bit further to go.

In one way the speck of an ant's brain seems disappointing, or absurd-the utter absence of choice, of love and passion. Yet as I watch the intricate complexity of the ant hill-their laying down chemical trails to a food source, or their "mouth to mouth" passing of regurgitated food samples to one another-it strikes me that humans could never achieve such communal efficiency and economy. And that we too are absurdly trapped by our design, by the labyrinth of language and reason. We drown in choices, in possibilities, and in self-consciousness-so much so that even emptying one's pockets or watching a hill of ants can feel like an epiphany.

I get up, walk out of the meadow and into the woods. A heavy mist hangs along the muddy bank of the river's oxbow like some foggy dream of Eden. Wildflowers are everywhere: purple phlox and yellow swamp lilies startle against the gray-green trees and muddy brown leaf bed. The stark white of three blooming dogwoods above me and the trillium below me look as if some god loaded a huge brush with pure white paint and gave it a shake here and there in the woods.

Even the most common birds are spectacular in the dripping dew. A hopping robin is aflame on the trail ahead of me. A goldfinch lights on a maple sapling in front of the dark mass of a huge cottonwood trunk. The raw yellow against the wet blackness distracts me from the rush of a plane overhead, and from the high-pitched binding of a circular saw somewhere beyond the trees.

Along the river I find the stretch where the trail always disappears in the thicket of the summer understory. I will be wading through the overgrowth feeling a bit unsure, look down, and suddenly it is gone. I don't know if I'm on the trail or making my own. I can't see it. And then, finally, I do-an opening trodden in the weeds. Yet it's not as if I was ever really lost. I know where the river and the farmhouse are, but it still startles me how quickly the trail disappears, how I can be looking right at it and not see it. 
A neighbor's dog on the other side of the river starts to howlloud and crazed, as if it is on a chain and has seen a rabbit. I think of an odd little essay I taught in my composition classes last week: "Looking for a Lost Dog," by Gretel Ehrlich-a story about walking. Ehrlich starts off with a clear purpose-to find her dog, which is lost in the Wyoming wilderness. But after a few paragraphs, it is clear that she has lost her way, and is searching for the much deeper wilderness of her self. She is torn open by her desires: "Some days I think this one place isn't enough," she writes. "I want to live multiple lives and be allowed to love without limits." But the more she notices and attends to her environment, the more she is able to see, the more at home she becomes, until she finally recognizes that "everything is here." She closes with this line: "Today it is enough to make a shadow."

"But what the hell's her point?" asks Bill, a bright and witty student. "She makes me feel like I'm lost in the woods!" Maybe that is her point, I say: we are all lost in the woods-in the bramble of human limitation and longing. And thus we don't notice or appreciate our ability to "make a shadow," the beauty of our simple presence, our human being. "Why doesn't she just say that, then?" Maybe she wants us to participate in it, to feel it, I say. Bill looks pensive, and ready for class to end.

Ehrlich also tips her hat to Thoreau in the essay. She includes this line from "Walking": "The saunterer is no more vagrant than the meandering river which is all the while sedulously seeking the shortest route to the sea." Students often choose this as Erhlich's thesis statement. Even though she didn't write it and they don't know what "sedulously" means (nor did I until I first read the essay), they sense this simile is at the heart of things. Since it is a provocative sentence and we are learning basic research skills, I often ask students to paraphrase it. Here are a few responses from one class.

"The walker should not be faulted for taking his time."

"To saunter is more about being led than leading."

"The saunterer is not 'guilty,' nor is he lazy. He is wise."

"The walker knows where he is going, just as the river knows where it is going." 
I like the last version--the idea that people and rivers both have the capacity to "know" important things, yet neither can understand the other's knowledge.

I walk through light and shadow, and then a dense quiet which is holding a word that I can smell but not yet see. I think it is "death." But perhaps it is "green." The decaying floor of the woods, the dried blanket of brittle leaves and crumbling mash of log and stick is perforated everywhere by green shoots, which are born to the light-maples and paw paws and hickories and trout lilies and many more-all resurrected by the magnet of the sun. It is here, kneeling in the dank rot of the woods, watching the ants and ticks and beetles walking to and fro, that I can imagine the paradox of arrival, of ending as beginning, of the moment when the river enters the sea, when movement becomes part of a vast deep stillness.

That night I look through my "seeds" file, a manila folder which I keep stuffing with clippings, with poems and quotes and photos I rely on as a reservoir of inspiration. I find some lines from a letter Thoreau wrote to Emerson the year his own brother, John, died of lockjaw, and Emerson's five-year-old son, Waldo, died of scarlet fever.

Death is "a law and not an accident," Thoreau wrote in his journal. "It is as common as life. When we look over the fields we are not saddened because the particular flowers or grass will witherfor the law of their death is the law of new life.... So it is with the human plant."

Thoreau frequently addresses this idea in his work: "the human plant" flourishes as a part of nature but withers in seeking to be apart from nature. Thus, for both the sturdy white pine and the sturdy young boy who climbs its sappy limbs, life is a glorious saunter toward death. Death is a miraculous walk toward life. But what makes the human most human is the in-between, the wildness of the Encounter, the unlocking of the present, of the eye and I-the constant awakening to both the world in which we find ourselves, and the world of our selves.

I walk up a steep hill, where I find my three favorite trees. The sycamore, beech, and cottonwood are all over one hundred feet tall. Their branches mingle in the sky, share leaping squirrels and nervous woodpeckers. Each tree has its own personality. The gray beech with its tough slick skin is a dinosaur's neck bending and 
stretching to feed in the canopy. Its translucent leaves allow more light to pass through. Today the sun casts lime-tinted rays through the beech leaves on to the ground. The bark of the cottonwood conjures not skin but armor-a tough range of peaks and crevices so deep my ten-year-old daughter can put her entire hand in one. The leaves of the cottonwood sapling are fat green hearts with thick red veins that so resemble an animal's circulatory system they seem to pulsate with life. And the leaves' flat stems mean they cannot spin but only bob from side to side in the wind, like they are constantly waving goodbye. The sycamore is the easiest to recognize of the trio, because it's always losing its skin. As it grows, the outer layer of bark can't keep pace and peels off into curling olive, white, and brown flakes. Thus it is typically dark on the lower half and bone white further up, where its molting is complete. I most like to visit this elderly trio in the winter, when they are "dead" and the sap has run out of their hearts, and the core of their relationship, their competition for light and water, has all but stopped. Then I like to stand near them, and listen to their creaking conversations as they scratch each other in the icy wind.

I keep walking. But I'm losing focus and starting to tire. I've stopped wandering and started wondering: How much further should I go? Should I not turn back, or at least point myself toward home? What time is it?

I sit on a rotten beech log to rest. The soft hollow of the tree is swarming with-what else-thousands of ants. Their perfect chaos again pulls me into a trance. A long black file marches across the soft wood like a sprawling prehistoric sentence. Each jointed body is an unpronounced letter, or an unspoken word, on its way to an idea hidden somewhere deep in the green mind of the woods. I follow the ants with my eyes until they hit their end mark, a dead sweat bee, where they heap up into a writhing mass of legs and mandibles.

This time the stream of ants reminds me not of Thoreau's content, but of his style, of how his long, winding sentences crawl into the soft tissue of the reader's brain, into mine, where the words pile into a wild throng of ideas. I am sometimes unsure if Thoreau is exploring the language of nature or the nature of language. Probably both. Maybe this is why reading Thoreau always leads me back into the woods, back to walking. 
Some days reading and walking seem like the same thing, like part of the same journey. Reading too is a kind of saunter, the sentences a faint path we track through the writer's consciousness. Some readers wander off in a direction the writer never imagined, following a faint, muddy paw print, or the warm ashes of a recent fire, toward some new idea or theme. Others get down on their hands and knees and savor the color and scent and flavor of certain words as if they were sacred. But many don't. Most of us want a clearly marked trail on which we can stop from time to time to briefly smell or touch or taste whatever is new, whatever momentarily startles or excites us. And then, like the ants, we need to get moving again, to march somewhere, to do something, to eat or have sex or change the oil, to try to arrive, and to avoid getting lost.

Maybe writers owe us this kind of clarity. Or maybe they don't. Maybe the point is that ants can't saunter, but people can, and so we should. Or maybe the point is that life is an ellipsis rather than a series of periods, that sauntering is all there really is, and the best sentences we will ever read or write or live only lead us deeper into the woods, into a place where keys and credit cards don't matter, a place where we once belonged, and still long to be.... 